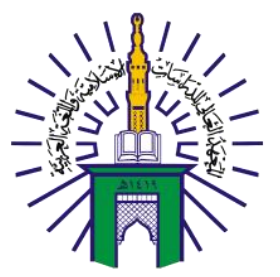

BUSTANUL FUQAHA:

JURNAL BIDANG HUKUM ISLAM

Vol. 2 No. 3 (2021): Hal. $432-444$

EISSN: 2723-6021

Website: https://journal.stiba.ac.id

\title{
ZAKAT TABUNGAN PENSIUN DALAM PERSPEKTIF FIKIH ISLAM
}

\section{ZAKAT OF PENSION SAVING IN ISLAMIC JURISPRUDENCE PERSPECTIVE}

\author{
Khaerul Aqbar \\ Sekolah Tinggi Ilmu Islam dan Bahasa Arab (STIBA) Makassar, Indonesia \\ Email: khaerul@stiba.ac.id \\ Dewi Indriani \\ Sekolah Tinggi Ilmu Islam dan Bahasa Arab (STIBA) Makassar, Indonesia \\ Email: dewiindriani@stiba.ac.id \\ Sulkifili Herman \\ Sekolah Tinggi Ilmu Islam dan Bahasa Arab (STIBA) Makassar, Indonesia \\ Email: sulkifliherman@stiba.ac.id \\ Selvi Wanda Rusmita \\ Sekolah Tinggi Ilmu Islam dan Bahasa Arab (STIBA) Makassar, Indonesia \\ Email: selviwanda@gmail.com
}

\begin{tabular}{|c|c|}
\hline Keywords : & ABSTRACT \\
\hline $\begin{array}{l}\text { retirement saving, zakat, } \\
\text { Islamic jurisprudence, } \\
\text { retirement. }\end{array}$ & $\begin{array}{l}\text { This research aims to find out the zakat obligations that must be paid by } \\
\text { a pensioner related to the retirement savings he receives at retirement. } \\
\text { This research used a qualitative descriptive research (non-statistical), } \\
\text { which focused on the study of manuscripts and texts. The results of this } \\
\text { study explain that retirement savings are legally equated with } \\
\text { receivables that are no longer expected to be paid (already hard to pay), } \\
\text { which are not subject to obligatory zakat, because pension savings } \\
\text { cannot be disbursed at any time by the beneficiary except at a specified } \\
\text { time, so even The savings are already sufficient in terms of nisab and } \\
\text { haulnya prospective beneficiaries are not yet obliged to pay zakat. } \\
\text { Beneficiaries may issue their zakat immediately after receiving the } \\
\text { benefits if the nisab has been fulfilled in a tatawwu '(not mandatory) } \\
\text { manner, even though the haul has not been sufficient. }\end{array}$ \\
\hline \multirow{2}{*}{$\begin{array}{l}\text { Kata kunci : } \\
\text { tabungan pensiun, zakat, } \\
\text { pensiun, fikih islam, pensiun }\end{array}$} & ABSTRAK \\
\hline & $\begin{array}{l}\text { Penelitan ini bertujuan untuk mengetahui kewajiban zakat yang harus } \\
\text { ditunaikan oleh seorang pensiun terkait tabungan pensiun yang ia terima } \\
\text { pada saat pensiun. Penelitian ini menggunakan metode penelitian } \\
\text { deskriptif kualitatif (non-statistik), yang terfokus pada studi naskah dan } \\
\text { teks. Adapun hasil dari penelitian ini menerangkan bahwa tabungan } \\
\text { pensiun disamakan hukumnya dengan piutang yang tidak lagi } \\
\text { diharapkan pembayarannya (sudah berat untuk dibayar), yang tidak } \\
\text { terkena wajib zakat, karena tabungan pensiun tidak bisa dicairkan kapan } \\
\text { saja oleh penerima manfaat kecuali pada waktu yang ditentukan, } \\
\text { sehingga meskipun tabungan tersebut sudah cukup nisab dan haulnya, } \\
\text { calon penerima manfaat belum wajib membayar zakatnya. Penerima } \\
\text { manfaat boleh langsung mengeluarkan zakatnya setelah menerima } \\
\text { manfaat jika telah terpenuhi nisabnya secara tatawwu' (bukan wajib) } \\
\text { meskipun belum cukup haulnya. }\end{array}$ \\
\hline
\end{tabular}




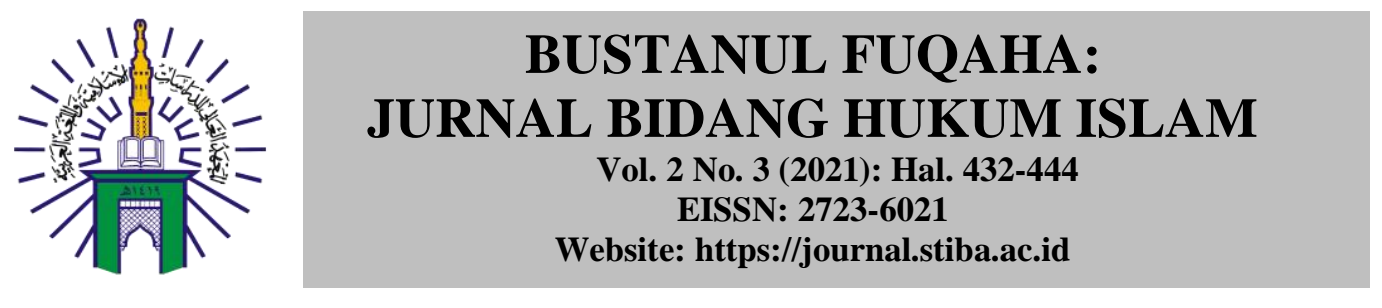

Diterima: 7 September 2021; Direvisi: 29 Oktober 2021; Disetujui: 10 November 2021; Tersedia online: 3 Desember 2021

How to cite: Khaerul Aqbar, Dewi Indriani, Sulkifli Herman, Selvi Wanda Rusmita. "Zakat Tabungan Pensiun dalam Perspektif Fikih Islam”, BUSTANUL FUQAHA: Jurnal Bidang Hukum Islam Vol. 2, No. 3 (2021): 382-394. doi: 10.36701/bustanul.v2i3.413.

\section{PENDAHULUAN}

Sebagai agama yang universal, Islam dibangun di atas lima penyangga utama yang disebut rukun Islam. Setelah syahadat yang diikrarkan seorang muslim, salat dan zakat merupakan dua rukun yang sering disebutkan secara beriringan di dalam ayat Al-Qur'an, diantaranya firman Allah swt. pada Q.S. al-Baqarah/2: 110,

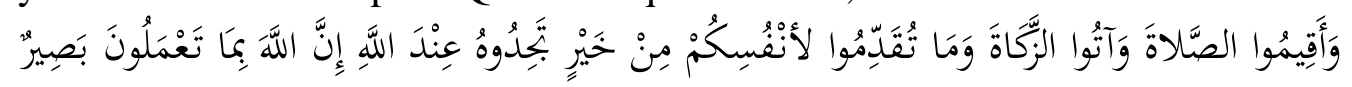

Terjemahnya:

"Dan laksanakanlah salat dan tunaikanlah zakat. Dan segala kebaikan yang kamu

kerjakan untuk dirimu, kamu akan mendapatkannya (pahala) di sisi Allah. Sungguh,

Allah Maha Melihat apa yang kamu kerjakan". ${ }^{1}$

Ulama menjelaskam bahwa di antara hikmah digandengkannya salat dan zakat adalah untuk menunjukkan keutamaan dan pentingnya zakat. $^{2}$ Salah satu urgensi menunaikan zakat adalah karena perintah ini mengandung misi sosial untuk mengangkat dari kemiskinan masyarakat yang kurang mampu yang mana zakat tersebut akan disalurkan kepada mereka yang membutuhkan dan menjaga kemaslahatan bersama sesama umat Islam. Zakat juga sangat berpengaruh dan bertujuan untuk menuntaskan atau meminimalisir problem kemiskinan, meratakan penghasilan dan juga untuk meningkatkan kesejahteraan umat dan negara.

Sejak awal disyariatkannya, kaum muslimin telah mengenal beberapa jenis harta yang wajib dikeluarkan zakatnya, di antaranya uang, barang tambang dan rikaz, barang dagangan, hasil bumi, buah-buahan, dan ternak, yaitu unta, sapi, dan domba. ${ }^{3}$ Seiring dengan berkembangnya kemajuan kehidupan manusia, telah menjadi konsekuensi logis ditemukannya berbagai persoalan dalam kehidupan manusia modern yang membutuhkan kepastian hukum syariat termasuk diantaranya persoalan zakat atau yang dikenal dengan istilah zakat kontemporer, seperti zakat profesi dan zakat tabungan pensiun.

Tabungan Hari Tua (THT) atau lebih dikenal dengan tabungan pensiun merupakan dana simpanan para pegawai yang merupakan bagian dari gaji yang dipungut secara berkala oleh instansi untuk disimpan dan hanya dapat diambil jika pekerja atau pegawai tersebut telah memasuki masa pensiun atau telah berhenti bekerja baik karena meninggal atau karena sebab lain. ${ }^{4}$

${ }^{1}$ Kementrian Agama RI, Al-Qur'an Dan Terjemahnya (Jakarta Timur: Ummul Qura, 2018). أكبر م. n.d.,

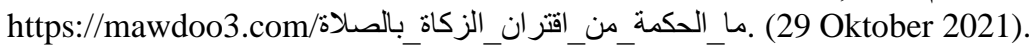

3 Wahbāh bin Mustafā Al-Zuhailī̄, "Al-Fīqhu Al-Islāmī Wa Adillatuhu, Jilid 3 (Damaskus" (Damaskus: Dārul fikr, n.d.), h. 1819.

4 "Tabungan Hari Tua," PT.Taspen, 2021, https://taspen.co.id/layanan/detail-tht. 


\section{BUSTANUL FUQAHA: \\ JURNAL BIDANG HUKUM ISLAM \\ Vol. 2 No. 3 (2021): Hal. 432-444 \\ EISSN: 2723-6021 \\ Website: https://journal.stiba.ac.id}

\section{BUSTANUL FUQAHA}

Jurnal Bidang Hukum Islam

Dalam prakteknya, jumlah dana yang diterima saat pensiun memiliki nominal yang cukup besar sehingga penting untuk mengetahui hukum dana tabungan yang diterima tersebut apabila telah mencapai jumlah nisab, apakah zakatnya wajib langsung dikeluarkan ataukah harus menunggu waktu haulnya sehingga hal ini dapat menimbulkan ketidakpastian hukum bagi seorang muslim terutama para pensiun.

Berdasarkan latar belakang di atas, masalah pokok penelitian ini adalah: apakah tabungan pensiun wajib dikeluarkan zakatnya? Bagaimana cara menghitung haul tabungan pensiun? Adapun tujuan penelitian ini adalah untuk mengetahui kewajiban yang harus ditunaikan oleh seorang pensiun terkait tabungan pensiun yang diterima pada saat pensiun.

Untuk mendapatkan jawaban atas permasalahan di atas, peneliti menggunakan jenis penelitian deskriptif kualitatif (non-statistik), yang terfokus pada studi naskah dan teks.

Dari pengamatan peneliti, telah banyak hasil penelitian yang ditulis terkait dengan masalah tabungan pensiun, di antaranya;

1. Jurnal berjudul Manajemen Lembaga Keuangan Non Bank Dana Pensiun Berdasarkan Prinsip Syariah yang ditulis oleh Marifah Yuliani. Penelitian ini bertujuan untuk mengetahui manajemen dana pensiun berdasarkan sistem syariah. Hasil penelitian ini menyebutkan bahwa di masyarakat sudah ada lembaga keuangan yang mengelola dana pensiun untuk masyarakat luas Indonesia yang berbasis syariah, di antaranya Bank Muamalat dengan produk Pensiun Terproteksi Muamalah dan juga di Lembaga Keuangan Asuransi Takaful. ${ }^{5}$

2. Jurnal berjudul Manajemen Dana Pensiun Syariah,yang ditulis oleh Efrita Norman dan Enah Pahlawati. Tujuan penelitian ini adalah untuk mengetahui perbedaan dana pensiun konvensional dengan dana pensiun Syariah serta bagaimana pengelolaan dana pensiun menurut syariah. Hasil dari penelitian ini ditemukan bahwa yang menjadi dasar pembeda dana pensiun Syariah dengan konvensional ialah dana pensiun Syariah memiliki beberapa keunggulan, di antaranya memiliki akad dalam setiap transaksinya; memiliki Dewan Pengawas Syariah; dan ketika peserta telat membayar iuran pensiun akan dikenakan hukuman akan tetapi hasil dari dana hukuman tersebut akan dialokasikan untuk kegiatan sosial sehingga disini terdapat unsur tolong menolong ( ta' $^{\prime} \bar{w} u n$ ) sesama manusia. ${ }^{6}$

3. Jurnal berjudul Tanggungjawab Otoritas Jasa Keuangan Terhadap Pengelolaan Dana Pensiun Syariah di Universitas Muhammadiyah Surakarta yang ditulis oleh Ani Yunita, Reni Budi Setyaningrum dan Muhammad Annas. Penelitian ini bertujuan untuk mengetahui pelaksanaan dan hambatan pengelolaan dana pensiun di Lembaga Dana Pensiun Universitas Muhammadiyah Surakarta (UMS) serta tanggungjawab Otoritas Jasa Keuangan Solo dalam menjalankan wewenang pengawasan terhadap pengelolaan dana pensiun di Lembaga Dana Pensiun Universitas Muhammadiyah Surakarta. Hasil penelitian menunjukkan bahwa

5 Marifah Yuliani, "Manajemen Lembaga Keuangan Non Bank Dana Pensiun Berdasarkan Prinsip Syariah," Journal of Chemical Information and Modeling 17, no. 2 (2019): 221-40.

6 Efrita Norman and Enah Pahlawati, "Manajemen Dana Pensiun Syariah," Reslaj: Religion Education Social Laa Roiba Journal 3, no. 2 (2021): 227-35, doi:10.47476/reslaj.v3i2.349. 


\section{BUSTANUL FUQAHA: \\ JURNAL BIDANG HUKUM ISLAM \\ Vol. 2 No. 3 (2021): Hal. 432-444 \\ EISSN: 2723-6021 \\ Website: https://journal.stiba.ac.id}

pengelolaan dana pensiun di UMS telah berjalan sesuai dengan peraturan, namun ada beberapa hambatan yaitu Pendiri dan Dewan Pengawas Syariah masih belum mendapatkan Surat Pengangkatan dari Dewan Syariah Nasional dan Majelis Ulama Indonesia. Pengawasan Otoritas Jasa Keuangan Solo terhadap pengelolaan dana pensiun syariah masih belum optimal. OJK dalam menegakkan syariah compliance bagi pelaku bisnis syariah di Lembaga Keuangan Syariah harus taat hukum. $^{7}$

Dari hasil penelitian-penelitian di atas, belum ada yang meneliti tentang zakat dana pensiun atau tabungan hari tua (THT).

\section{PEMBAHASAN}

\section{Zakat Mal (Harta)}

Zakat secara bahasa adalah menyucikan sesuatu: apabila berkembang dan bertambah, maka zakat dapat berarti keberkahan, berkembang, kesucian, dan kebaikan. ${ }^{8}$ Adapun zakat menurut istilah syariat adalah hak wajib dari harta tertentu, untuk golongan tertentu dan pada waktu tertentu. ${ }^{9}$ Menurut Ibnu Qudāmah al-Maqdisī, zakat adalah hak wajib dalam harta. ${ }^{10}$

Zakat termasuk dalam kategori ibadah māliyah (harta) yang telah diatur secara rinci dan paten berdasarkan Al-Qur'an dan sunah, sekaligus merupakan amal sosial kemasyarakatan dan kemanusiaan yang dapat berkembang sesuai dengan perkembangan umat manusia.

Zakat mulai disyariatkan pada tahun kedua Hijriyah. ${ }^{11}$ Adapun dasar hukum dalil AlQur'an, di antaranya firman Allah swt. berikut ini:

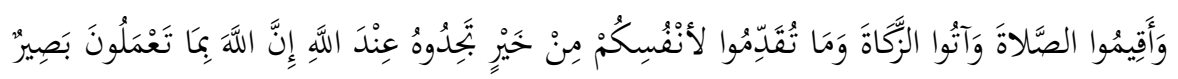

Terjemahnya:

"Dan dirikanlah salat dan tunaikanlah zakat. dan kebaikan apa saja yang kamu usahakan bagi dirimu, tentu kamu akan mendapat pahala nya pada sisi Allah. Sesungguhnya Alah Maha melihat apa-apa yang kamu kerjakan."12 (Q.S. al-Baqarah/2: 110)

$$
\text { ........ بَأَقِيمُوا الصَّلاةَ وَآتُوا الزَّكَاةَ. }
$$

Terjemahnya:

“... dan dirikanlah sembahyang, tunaikanlah zakat ... ${ }^{13}$ (Q.S. al-Muzammil/73: 20)

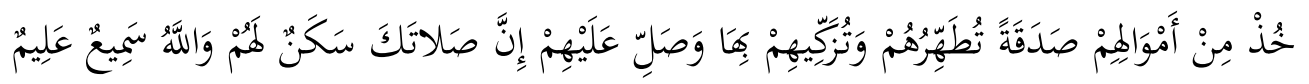

${ }^{7}$ Ani Yunita and Reni Budi Setyaningrum Muhammad Annas, "TANGGUNGJAWAB OTORITAS JASA KEUANGAN SOLO DI LEMBAGA DANA PENSIUN UNIVERSITAS," Masalah-Masalah Hukum 47, no. 4 (2018): 460-78, doi:10.14710/mmh.47.4.2018.460-478.

${ }^{8}$ Kamāl ibn al-Sayyid Sālim, "Șaḥịh Fiqh Al-Sunnah Wa Adillatuh Wa Tauḍịh Mażāhib Al-Aimmah" Jilid. 2 (al-Qāhirah: al-Maktabah al-Tauqīfiyyah, 2003), h. 5.

${ }^{9}$ Șālih bin Fauzān bin "Abdullah al-Fauzān, "Al-Mulakhkhașal-Fiqhī," Cet. XIV (Kerajaan Saudi Arabia: Dār Ibnu al-Jauzī, 2000), h. 222.

${ }^{10}$ Abdullah bin Aḥmad Ibnu Qudāma, “Al-Mugn̄̄”, Jilid 5. (al-Riyāḍ: Dār ‘Ālam al-Kutub, 2015), h.

5.

${ }^{11}$ al-Fauzān, "Al-Mulakhkhașal-Fiqhī, h. 222.

${ }^{12}$ RI, Al-Qur'an Dan Terjemahnya, h. 18.

${ }^{13}$ RI, Al-Qur'an Dan Terjemahnya, h. 18. 


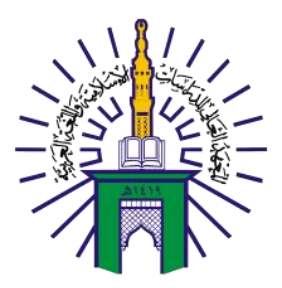

\section{BUSTANUL FUQAHA: \\ JURNAL BIDANG HUKUM ISLAM \\ Vol. 2 No. 3 (2021): Hal. 432-444 \\ EISSN: 2723-6021 \\ Website: https://journal.stiba.ac.id}

Terjemahnya:

a) "Ambillah zakat dari sebagian harta mereka, dengan zakat itu kamu membersihkan dan mensucikan mereka dan mendoalah untuk mereka. Sesungguhnya doa kamu itu (menjadi) ketenteraman jiwa bagi mereka. dan Allah Maha mendengar lagi Maha mengetahui". ${ }^{14}$ (Q.S. al-Taubah/9: 103)

Hadis Nabi saw. menyebutkan betapa zakat sangat asasi atas tegaknya Islam, selain dari syahadat, salat, dan rukun Islam lainnya, sebagaimana sabda Rasulullah saw.,

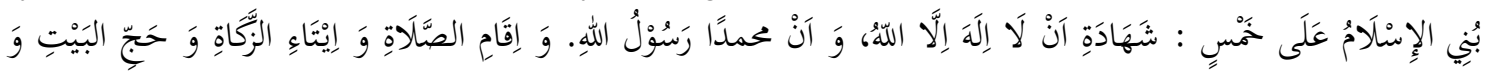

15 صَوْمُ رَمَضَانَ.(رواه البخاري و مسنِ :

Artinya:

"Islam itu dibangun atas lima dasar: menyaksikan bahwa tidak ada Tuhan yang berhak disembah selain Allah, dan bahwasanya Muhammad itu Rasul-Nya, mendirikan salat, menunaikan zakat, mengerjakan haji, dan berpuasa pada bulan Ramadhan."(H.R. Bukhari dan Muslim)

Yusuf al-Qardāwī menjelaskan dalam kitabnya Fiqh al-Zakah bahwa zakat maal meliputi sembilan sektor; pertama, emas, perak, dan barang berharga lainnya; kedua, aset perdagangan; ketiga, hewan ternak; keempat, hasil pertanian; kelima, hasil olahan tanaman dan hewan; keenam, hasil tambang dan tangkapan laut; ketujuh, hasil penyewaan asset; kedelapan, hasil jasa profesi; kesembilan, hasil saham dan obligasi. ${ }^{16}$

Sektor zakat yang disebutkan oleh Yusuf al-Qardāwī hampir sama yang ditetapkan dalam Undang-Undang (UU) Nomor 23 Tahun 2011, dimana zakat mal meliputi; emas, perak, dan logam mulia lainnya; uang dan surat berharga lainnya; perniagaan; pertanian, perkebunan, dan kehutanan; peternakan dan perikanan pertambangan; perindustrian; pendapatan dan jasa; dan rikaz. ${ }^{17}$

Ada beberapa syarat wajib zakat yang telah ditetapkan para ulama fikih yang harus dipenuhi dalam harta, yaitu: ${ }^{18}$

a. Al-milku al-tām (kepemilikan sempurna), yaitu pemilik wajib berzakat apabila hartanya berada di bawah kekuasaannya secara utuh. Harta umat tidak terkena kewajiban zakat begitu pula harta haram.

b. Al-nama'u (harta produktif), yaitu harta yang terkena kewajiban zakat adalah harta yang berkembang secara produktif atau berpotensi produktif. Pengertian berkembang yaitu harta menghasilkan keuntungan atau pendapatan lain. Harta yang berkembang dapat digunakan sebagai modal usaha atau bisnis berkelanjutan, misalnya sawah, perdagangan, ternak, emas, perak, dan uang

c. Sampai nisab, yaitu harta yang tidak mencapai nisab (jumlah tertentu sesuai ketentuan syariat) maka tidak wajib dizakati.

d. Melebihi kebutuhan pokok.

\footnotetext{
${ }^{14} \mathrm{RI}$, Al-Qur'an Dan Terjemahnya, h. 18.

${ }^{15}$ Muḥammad ibn Ismā̄̄îl ibn Ibrāhīm Al-Bukhārī, Șah̄̄h Al-Bukhārī, Cet. I (al-Qāhirah: Dār ibn alJauzī, 2010), h. 12.

${ }^{16}$ Yusuf Al-Qardhawi, "Fikih Al Zakah" (Azar, 2006), h. 124.

${ }^{17}$ President Republik Indonesia, "Undang-Undang No. 23 Tahun 2011 Tentang Pengelolaan Zakat" (Jakarta, 2011).

${ }^{18}$ Al-Qardhawi, "Fikih Al Zakah.”, h. 128- 164.
} 
e. Kelebihan dari pembayaran utang.

f. Cukup haul atau kepemilikannya genap satu tahun. Sebagian sector zakat tidak dipersyaratkan haul, seperti zakat pertanian yang dikeluarkan zakatnya setiap panen.

\section{Hikmah Zakat}

Ada beberapa hikmah zakat di antara lain: ${ }^{19}$

a. Zakat adalah benteng harta.

Dengan membayar zakat dapat melindungi harta dari pandangan hasad yang bisa membuat kerusakan pada harta dan juga melindungi harta dari tangan orang orang jahat. Rasulullah saw. bersabda,

$$
\text { حصِّنو ا أمو الكم بالزكاة، وداووا مرضاكم بالصدقة، و أعدّو اللبلاء الدعاء20 }
$$

Artinya:

"Bentengilah harta kalian dengan zakat, obatilah orang sakit di antara kalian dengan sedekah dan cegahlah musibah dengan doa."

b. Menuntaskan kesenjangan social.

Dengan zakat, kesenjangan sosial dapat diatasi, ${ }^{21}$ sekaligus dapat membantu perekonomian masyarakat, sehingga tarwujudlah masyarakat yang harmonis dan saling tolong menolong. Zakat dapat menjadi sarana membina kaum ekonomi duafa (orang yang lemah secara ekonomi) maupun mustahik lainnya ke arah kehidupannya yang lebih baik dan lebih sejahtera.

b. Sebagai perwujudan iman kepada Allah.

Zakat merupakan salah satu dari rukun Islam, wujud dari mensyukuri nikmat-Nya, menumbuhkan akhlak mulia dengan memiliki rasa kemanusiaan yang tinggi, menghilangkan sifat kikir dan rakus dengan berupaya menunaikan hak orang lain yang ada padanya. ${ }^{22}$

\section{Zakat Tabungan Pensiun}

\section{Pengertian Tabungan Pensiun}

Tabungan Hari Tua (THT) atau lebih dikenal dengan tabungan pensiun merupakan dana simpanan para pegawai yang merupakan bagian dari gaji yang dipungut secara berkala oleh instansi untuk disimpan dan hanya dapat diambil jika pekerja atau pegawai tersebut telah memasuki masa pensiun atau telah berhenti bekerja baik karena meninggal atau karena sebab lain. ${ }^{23}$

Tabungan pensiun dikelola dan dikembangkan oleh lembaga atau badan hukum pengelola dana pensiun untuk memberikan kesejahteraan kepada karyawan suatu perusahaan, terutama yang telah pensiun. ${ }^{24}$ Pada dasarnya, tabungan pensiun adalah salah satu solusi untuk memberikan jaminan kesejahteraan kepada karyawan. Dana pensuin

\footnotetext{
${ }^{19}$ Hikmat Kurnia and A. Hidayat, Panduan Pintar Zakat (Jakarta: Qultum Media, 2008).

${ }^{20}$ Sulaiman bin Ahmad al Tabrani, “Al Du'aau Li Al Tabrani,” Cet I. Jilid. I (Baeirūt: dar al kutul al 'alamiyah, 1992), h. 35

21 Djaelani, Stategi Bazis Dalam Menyiasati Implemantasi UU No. 38 Tahun 1999 Tentang Pengelolaan Zakat (Jakarta: Forum Zakat, 2003).

${ }^{22}$ Mardani, Hukum Islam Dalam Hukum Positif Indonesia, Cet. I (Depok: Rajawali Pers, 2018).

${ }^{23}$ Taspen"Tabungan Hari Tua", situs resmi PT.Taspen. https://taspen.co.id/layanan/detail-tht. (4 September 2021)

${ }^{24}$ Julius R. Latumaerissa, Bank Dan Lembaga Keuangan Lain (Salemba Empat, 2011), h. 138.
} 


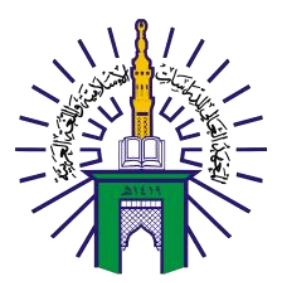

\section{BUSTANUL FUQAHA: \\ JURNAL BIDANG HUKUM ISLAM \\ Vol. 2 No. 3 (2021): Hal. $432-444$ \\ EISSN: 2723-6021 \\ Website: https://journal.stiba.ac.id}

tersebut dapat menjadi solusi bagi para pekerja dalam memperkecil masalah-masalah yang timbul dari resiko hidup yang akan dihadapi ke depannya. Sejak Undang-Undang Nomor 11 Tahun 1992 diberlakukan, hanya ada dua lembaga yang dapat menyelenggarakan program dana pensiun di Indonesia, yaitu Dana Pensiun Lembaga Keuangan (DPLK) dan Dana Pensiun Pemberi Kerja (DPPK).

\section{Jenis Dana Pensiun}

Jenis-jenis Dana pensiun sebagai berikut: ${ }^{25}$

a. Dana Pensiun Pemberi Kerja (DPPK): Yang dibentuk dan dikelola oleh perusahaan untuk memberikan program dana pensiun bagi karyawannya.

b. Dana Pensiun Lembaga Keuangan (DPLK): Yang dididrikan oleh bank atau perusahaan asuransi jiwa bagi masyarakat umum, baik karyawan maupun pekerja mandiri.

\section{Manfaat dan Kelemahan Jaminan Pensiun}

Pada dasarnya, dana pensiun diberikan dengan tujuan memberikan jaminan pendapatan bulanan seumur hidup bagi karyawan bersangkutan dan keluarga mereka. Tentu saja ada ketentuan yang harus dipenuhi untuk bisa menerima dana ini, seperti: ${ }^{26}$

a. Pensiun Hari Tua, diterima karyawan yang pensiun sampai meninggal dunia.

b. Pensiun Cacat, diterima karyawan bersangkutan akibat kecelakaan atau penyakit sampai meninggal dunia.

c. Pensiun Janda/Duda, diterima oleh janda/duda ahli waras karyawan pensiunan bersangkutan sampai meninggal dunia atau menikah lagi.

d. Pensiun Anak, diterima anak sebagai ahli waris karyawan pensiunan bersangkutan sampai menginjak umur 23 tahun, bekerja atau menikah.

e. Pensiun orang tua, diterima orang tua ahli waris karyawan pensiunan sampai batas waktu yang ditentukan UU.

f. Setelah memenuhi masa iuran minimal 15 tahun.

g. Jika karyawan pensiunan meninggal dunia pada masa pembayaran tersebut, ahli waris tetap berhak mendapatkan dana pensiun.

Adapun kelemahan dari tabungan pensiun, yaitu:

a. Perusahaan menanggung resiko atas kekurangan dana apabila hasil investasi tidak mencukupi.

b. Relatif lebih sulit untuk diadministrasikan.

c. Penghasilan pada saat mencapai usia pensiun lebih sulit untuk diperkirakan.

d. Karyawan menanggung resiko atas ketidakberhasilan investasi.

e. Tidak dapat mengakomodasikan masa kerja yang telah dilalui karyawan.

\section{Sistem Perhitungan Zakat Tabungan Pensiun}

Usia merupakan salah satu batas mutlak seseorang untuk selesai dari tanggung jawab bekerja. Biasanya setelah usia seseorang mencapai batas pensiun, akan mendapatkan tabungan pensiun. Tabungan pensiun tersebut merupakan hak dari orang yang bekerja

${ }^{25}$ Elvina Octavia Bukit, "Analisis Penerapan Pernyataan Standar Akuntansi Keuangan 18 Mengenai Akuntansi Dana Pensiun Pada Pertamina”.” (Universitas Hasanuddin, 2012), h. 13-14.

26 Ibid. 
yang telah diraih dengan segala hal (waktu, tenaga, pikiran) dan digunakan untuk tempat kerjanya.

Setiap pekerja memiliki jumlah gaji pensiun yang berbeda-beda. Tabungan pensiun yang di dapatkan oleh setiap pekerja dengan jumlah yang besar bahkan bisa jadi melewati batas wajib zakat. Mengapa demikian? Hal ini karena pada intinya, dari sumber manapun rezeki didapatkan, harta yang telah menjadi milik sah seseorang lalu disimpan, akan memiliki potensi untuk dikeluarkan zakatnya. Bila zakat tersebut merupakan dana simpanan atau dana tabungan maka ketentuannya mengikuti zakat emas, baik dalam hal syarat nisab maupun kadar zakat dan haulnya.

Tabungan pensiun bila konteksnya disimpan, dapat dikelompokkan menjadi harta simpanan, bila telah mencapai batas nisab emas maka berarti wajib dikeluarkan zakatnya. Sebagian ulama juga berpendapat bahwa sebaiknya zakat atas tabungan pensiun langsung dikeluarkan oleh pemiliknya begitu mendapatkannya.

Terdapat beberapa kondisi dalam penunaian zakat untuk pensiun, yaitu:

1. Bila tabungan pensiun didapatkan utuh belum dikurangi dengan zakatnya, maka perlu dihitungkan terlebih dahulu. Lalu, bila memang telah telah mencapai batas nisab, segera keluarkan zakatnya.

2. Bila tabungan pensiun yang didapatkan telah dikurangi dengan zakat lantas tidak perlu dikeluarkan zakatnya. Namun, bila sampai tahun berikutnya jumlah simpanan tabungan pensiun masih memenuhi batas nisab zakat, maka perlu dan wajib dikeluarkan zakatnya.

Contoh kasus, misalnya, Pak Ahmad menerima pensiun sebesar Rp.500.000,000. Ternyata dari perusahaan tempat pak Ahmad bekerja tersebut belum ada potongan berupa zakat. Padahal pak Ahmad ingin sekali bisa berzakat melalui tabungan pensiunnya. Berapa jumlah uang yang harus dikeluarkan oleh pak Ahmad? Jawabannya adalah: nisab zakat emas: 85 gram atau setara dengan nilai 85 x Rp.743.000,- $=$ Rp.63.155.000,-. Tabungan pensiun yang dimiliki oleh pak Ahmad sudah memenuhi batas nisabnya, maka harus dikeluarkan zakatnya sebesar : 2,5\% x Rp.500.000.000,- = Rp.12.500.000,-. Jadi, besar zakat yang dikeluarkan Pak Ahmad dari uang yang diterimanya adalah sebesar Rp.12.500.000,-.

\section{Perspektif Hukum Islam Terhadap Zakat Tabungan pensiun}

Zakat adalah salah satu rukun Islam, dimana setiap kaum muslimin memilki kewajiban untuk melaksanakan zakat tersebut, dan dengan zakat inilah kaum muslimin menyalurkan sebagian dari harta yang di milikinya. Namun kaum muslimin memiliki berbagai macam sumber dalam mendapatkan harta atau uang tersebut, salah satu sumber harta yaitu dengan bekerja misalnya adalah menjadi Pegawai Negeri Sipil (PNS). Bahkan sangat banyak dari masyarakat berminat dalam pekerjaan ini dengan tujuan memperoleh tabungan, walaupun terkadang gaji bulanan tidak cukup untuk menafkahkan kehidupan keluarga. Namun pekerjaan ini mendapatkan gajii pensiun di masa tua, gaji pensiun tersebut didapatkan dari hasil potongan gaji pekerja setiap bulannya.

Hakikat tabungan pensiun adalah sejumlah dana yang diperoleh seorang PNS dari intansinya ketika ia mengakhiri masa kerjanya. Tabungan tersebut sebenarnya bukan mutlak hadiah instansi kepada mantan pegawainya. Ia adalah hasil kumpulan dana tertentu setiap bulan selama masa kerjanya ditambah kompensasi akhir masa kerja dari 


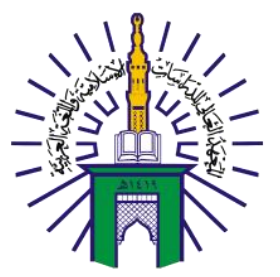

\section{BUSTANUL FUQAHA: \\ JURNAL BIDANG HUKUM ISLAM \\ Vol. 2 No. 3 (2021): Hal. $432-444$ \\ EISSN: 2723-6021 \\ Website: https://journal.stiba.ac.id}

instansinya. ${ }^{27}$ Tabungan pensiun yang diterima setelah berakhirnya masa kerja, tidak wajib dikeluarkan zakatnya karena ada salah satu syarat wajib zakat yang belum terpenuhi yakni haul. Walaupun potongan gaji bulanan tersebut disimpan dan ditabung oleh instansi namun tabungan pensiun belum menjadi miliknya secara sempurna karena masih di bawah kepemilikan instansi dan pegawai tidak berhak memiliki uang tersebut apalagi mengambilnya. Tabungan pensiun mutlak menjadi miliknya setelah berakhirnya masa kerja pegawai tersebut.

Namun perlu diketahui bahwasannya saat menerima tabungan pensiun dan telah mencapai nisab tetapi belum mencapai haul, maka hari ketika ia menerima tabungan pensiun menjadi permulaan untuk menghitung haul tabungan tersebut, agar tahun yang akan datang dapat mencapai haul dan bisa dikeluarkan zakatnya.

Menurut Muhammad Shalih al-Utsaimin, tidak apa-apa mendapatkan dana pensiun, sebab ia merupakan bagian dari gaji pegawai yang disimpan oleh negara untuk saat-saat yang membutuhkan. Tunjangan pensiunan yang diambil dari gaji tidak wajib zakat, sebab pemiliknya tidak dapat mengambilnya kecuali dengan persyaratan tertentu. Ia seperti piutang pada orang yang kesusahan dan piutang pada orang susah tidak wajib zakat. Tetapi jika menerimanya, yang lebih hati-hati adalah menzakatinya satu kali saja untuk satu tahun. ${ }^{28}$

Menurut Muhammad al-Ghazali, orang bekerja dengan penghasilan yang melebihi petani, wajib mengeluarkan zakat. Hal ini berarti bahwa zakat gaji pensiun dikiaskan dengan zakatnya pertanian. Ia berkata,

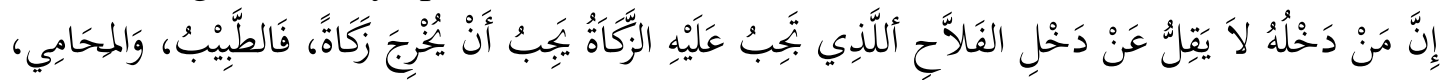

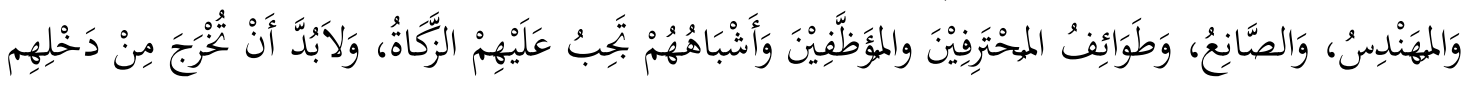

$$
\begin{aligned}
& \text { الكَبِيْرِ }
\end{aligned}
$$

Artinya :

"Sesungguhnya orang yang pemasukannya tidak kurang dari petani yang diwajibkan zakat, maka ia wajib mengeluarkan zakat. Karenanya, dokter, pengacara, insinyur, pengrajin, para pekerja profesional, karyawan, dan sejenisnya, wajib zakat atas mereka. Dan zakatnya harus dikeluarkan dari pendapatan mereka yang besar".

Pandangan ini didasari atas dua alasan, yaitu:

Pertama, keumuman firman Allah swt.pada Q.S. al-Baqarah/2: 263,

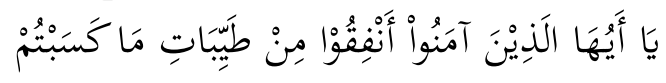

Terjemahnya:

\footnotetext{
${ }^{27}$ Muhammad Yassir, “Zakat Tabungan Pensiun,” 2020, https://konsultasisyariah.com/17499-zakatuang-pensiun-dan-klaim-asuransi.html $\quad$ l. https://konsultasisyariah.com/17499-zakat-uang-pensiun-danklaim-asuransi.html (29 April 2020).

${ }^{28}$ Muhammad Shalih al- Utsaimin, Ensiklopedia Zakat (Pustaka As-Sunnah, n.d.), h. 58.

29 Muhammad Al-Ghazali, “Al-Islām Wa Audla'una Al-Iqtishādiyyah," Cet.I (Mesir: Ḋār anNahdhoti, 2006), h.118.
} 


\section{BUSTANUL FUQAHA: \\ JURNAL BIDANG HUKUM ISLAM \\ Vol. 2 No. 3 (2021): Hal. $432-444$ \\ EISSN: 2723-6021 \\ Website: https://journal.stiba.ac.id}

"Hai orang-orang yang beriman nafkahkanlah (di jalan Allah) sebagian dari hasil usahamu yang baik-baik. ${ }^{30}$

Kedua, secara rasional, Islam telah mewajibkan zakat atas petani. Jika petani saja penghasilannya lebih rendah dari mereka diwajibkan zakat, apalagi mereka yang penghasilannya lebih tinggi dari petani. ${ }^{31}$

Salah satu dalil atau hadis yang menunjukkan bahwasanya emas, perak dan uang merupakan kekayaan yang wajib dikeluarkan zakatnya dengan syarat mencapai nisab beserta haulnya adalah firman Allah dalam Q.S. al-Taubah/9: 34-35,

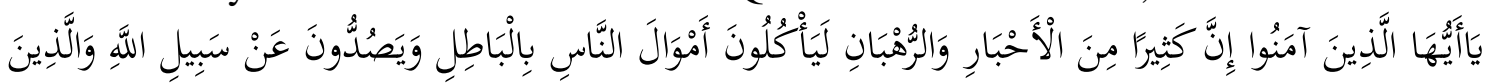

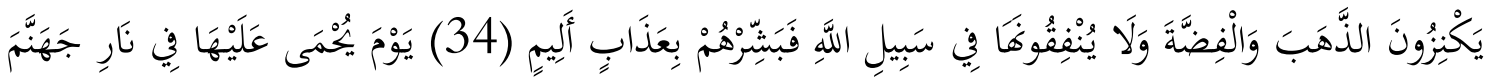

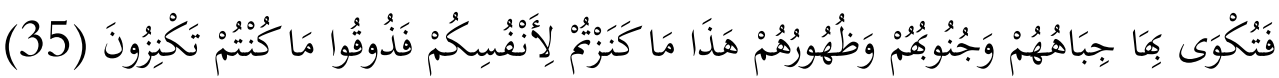

Terjemahnya:

"Hai orang-orang yang beriman, Sesungguhnya sebahagian besar dari orang-orang alim Yahudi dan rahib-rahib Nasrani benar-benar memakan harta orang dengan jalan batil dan mereka menghalang-halangi (manusia) dari jalan Allah. dan orang-orang yang menyimpan emas dan perak dan tidak menafkahkannya pada jalan Allah, Maka beritahukanlah kepada mereka, (bahwa mereka akan mendapat) siksa yang pedih,"“"Pada hari dipanaskan emas perak itu dalam neraka Jahannam, lalu dibakar dengannya dahi mereka, lambung dan punggung mereka (lalu dikatakan) kepada mereka: "Inilah harta bendamu yang kamu simpan untuk dirimu sendiri, Maka rasakanlah sekarang (akibat dari) apa yang kamu simpan itu." ${ }^{2}$

Yusuf al-Qarḍāwī menuliskan dalam kitabnya, Fiqh al-Zakah, bahwasanya uang kertas wajib dikeluarkan zakatnya. Beliau mengatakan bahwa uang kertas dengan dasar ketentuan pemerintah dan praktek nyata sudah menjadi nilai atas suatu harta, menjadi modal, dan juga untuk keperluan jual beli, juga digunakan sebagai pemasukan di setiap Negara. Dan uang gaji, upah dan mukafāah yang diberikan. ${ }^{33}$

Ulama kontemporer berbeda pendapat mengenai hukum zakat gaji pensiun sebelum diterima, terbagi menjadi tiga pendapat, yaitu:

Pertama, zakat gaji pensiun tersebut wajib dikeluarkan. Penerima gaji pensiun tersebut wajib untuk mengeluarkan zakatnya setiap tahun walaupun tabungan pensiun tersebut belum diterima. Pendapat ini yang dirajihkan oleh Yusuf al-Qardāwī. Beliau mengatakan bahwasanya kepemilikan terhadap uang tersebut termasuk kepemilikan yang sempurna karena diumpamakan seperti utang yang diharapkan (akan kembali). Sebagaimana yang dikatakan oleh Abu Ubaid bahwa gaji pensiun tersebut sama kedudukannya dengan harta yang ada di tangan yang wajib dikeluarkan zakatnya setiap mencapai haul apabila nisabnya telah terpenuhi. Begitu pula telah terpenuhi syarat yang lain yaitu terbebas dari utang dan lainnya. ${ }^{34}$

\footnotetext{
${ }^{30}$ RI, Al-Qur'an Dan Terjemahnya, h. 45.

${ }^{31}$ RI, Al-Qur'an Dan Terjemahnya, h. 45.

${ }^{32}$ Yusuf Qardawi, Fiqhu Zakāh, Cet. II (Bairūt: Muassasat ar- Risālah, 1973), h.273

${ }^{33}$ Yusuf Qardawi, Fiqhu Zakāh, h.273

${ }^{34}$ Muhammad bin Sa'id bin Fahd Ad-Dausiri, “Al-Rātib Al-Taqāudi Dirāsatu Fiqhiyyah” n.d., h.
} 217-220. 
Kedua, zakat gaji pensiun tersebut tidak wajib dizakatkan. Apabila gaji pensiun tersebut diterima maka pegawai atau pensiun tersebut menggabungkan dengan harta lainnya yang ia miliki. Dalil terhadap pendapat ini adalah:

a) Bahwasanya gaji pensiun tersebut tidaklah dianggap sebagai miliknya secara sempurna kecuali setelah jika telah diterima karena orang tersebut tidak berhak atas gaji pensiun kecuali setelah masa kerjanya berakhir. Gaji pensiun tersebut belum menjadi miliknya sampai ia menerimanya karena syarat paling penting wajibnya zakat yaitu kepemilikan secara sempurna terhadap harta yang ia miliki. Sedangkan kepemilikan tabungan pensiun dianggap antara ada dan tidak ada wujudnya, dan boleh jadi penerimaan terhadap harta pensiun dibatalkan apabila ada syarat yang dilanggar maka pensiun tersebut tidak berhak menerimanya.

b) Bahwasanya pekerja tidak dapat mengalihkan gaji pensiun tersebut kecuali setelah masa kerjanya berakhir.

c) Bahwasanya gaji pensiun tersebut disatukan dengan harta yang lainnya sehingga ia wajib menzakatinya ketika telah sempurna masa haulnya karena gaji pensiun tersebut dianggap seperti māl mustafad. Hukum māal Mustafad itu dikumpulkan bersama harta yang lain ketika telah mencapai haul dan nisab.

Ketiga, gaji pensiun tersebut tidak wajib dizakati dan apabila pegawai tersebut telah menerimanya maka pensiun tersebut harus menunggu lagi sampai tahun selanjutnya. Dalil terhadap pendapat ini adalah:

a) Dikiaskan atas utang yang sulit untuk dibayar. Sedangkan utang yang sudah dibayar tidak ada zakat padanya, maka begitu pula juga dengan gaji pensiun tersebut karena tidak memungkinkan untuk mengalihkannya kepada yang lain sebelum diterima. Jadi ketika utang yang sulit dibayar tersebut tidak wajib dizakati maka terlebih lagi untuk gaji pensiun karena tidak adanya kemungkinan peralihan di dalamnya.

b) Bahwasanya harta tersebut belum dimiliki sehingga orang tersebut terhalang dari hartanya yang mana harta tersebut tidak memberikan manfaat kepada pemiliknya. Dia tidak wajib menzakatinya sebagaimana kedudukan harta makātab. Karena sebab wajibnya zakat yaitu adanya harta yang berkembang. Dan tidak mungkin akan berkembang kecuali setelah adanya kemampuan untuk beralih. Sedangkan kondisi ini tidak dimiliki oleh gaji pensiun yang belum diterima.

c) Bahwasanya kepemilikan pegawai terhadap gaji pensiun ataupun lainnya hal tersebut dibatasi oleh aturan yang mana hak-hak pegawai tersebut diatur oleh aturan bahwasannya seorang pegawai tidak berhak atas gaji pensiun ataupun yamg selainnya kecuali setelah bekahirnya masa kerja. Sebagaimana ia tidak berhak terhadap gaji pensiun kecuali setiap akhir bulan setelah berakhirnya masa kerja. Pada kondisi tersebut, telah hilang syarat penting dari wajib zakat yaitu kepemilikan secara sempurna. Pegawai tersebut tidak berhak untuk meminta haknya sampai berakhirnya masa kerja. Hal ini menunjukkan tidak adanya kewajiban zakat terhadap pegawai tersebut. $^{35}$

Pendapat yang paling kuat adalah pendapat yang ketiga yang mengatakan bahwasanya gaji pensiun tidak wajib dizakati kecuali setelah diterima, berlalunya haul

${ }^{35}$ Ibid., h. 223. 


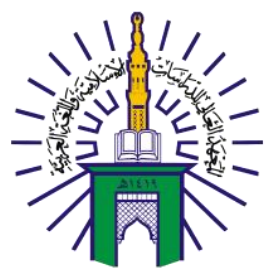

\section{BUSTANUL FUQAHA: \\ JURNAL BIDANG HUKUM ISLAM \\ Vol. 2 No. 3 (2021): Hal. 432-444 \\ EISSN: 2723-6021 \\ Website: https://journal.stiba.ac.id}

setelah diterima dan mencapainya nisab setelah diterima. Jadi ketika ia menerima gaji pensiun tersebut maka ia harus menunggu haul yang baru. ${ }^{36}$

Menurut Abdullah bin Manshur al-Ghufaili, terhadap pertanyaan: apakah tabungan pensiun wajib dikeluarkan zakatnya setelah diterima dan dikumpulkannya bersama harta yang lain ketika mencapai haul dan nisabnya ataukah menunggu dua haul setelah diterimanya tabungan pensiun tersebut? Masalah ini terdapat dua pendapat: ${ }^{37}$

Pertama, wajib dikeluarkan zakatnya dengan mengumpulkan harta tersebut dengan harta yang lainnya ketika telah mencapai haul dan nisabnya. Pendapat ini merupakan fatwa Nadwah yang kelima. Alasan pendapat pertama bahwasanya gaji pensiun diibaratkan sebagai al-māl al-mustafād, hukumnya dikumpulkan bersama lainnya yang sejenis dalam haul dan nisabnya.

Kedua, tidak wajib dikeluarkan zakat pensiun kecuali mencapai dua haul setelah diterimanya uang tersebut. Ini merupakan pendapat Lajnah al-Dāimah lil Buhūs alIlmiyah wa al-Ifta'. Alasan pendapat kedua adalah bahwasanya gaji pensiun tersebut merupakan al-māl al-mustafād yang tidak memperoleh perkembangan dari harta tersebut.

Pendapat yang rajih dalam masalah ini adalah pendapat kedua dimana harta tersebut dikeluarkan zakatnya setelah mencapai dua haul.

\section{KESIMPULAN}

Penelitan ini bertujan untuk mengetahui mengetahui kewajiban zakat yang harus ditunaikan oleh seorang pensiun terkait tabungan pensiun yang diterima pada saat pensiun. Hasil dari penelitian ini menerangkan bahwa tabungan pensiun disamakan hukumnya dengan piutang yang tidak lagi diharapkan pembayarannya (sudah berat untuk dibayar), yang tidak terkena wajib zakat, karena tabungan pensiun tidak bisa dicairkan kapan saja oleh penerima manfaat kecuali pada waktu yang ditentukan, sehingga meskipun tabungan tersebut sudah cukup nisab dan haulnya calon penerima manfaat belum wajib membayar zakatnya. Penerima manfaat boleh langsung mengeluarkan zakatnya setelah setelah menerima manfaat jika telah terpenuhi nisabnya secara tațawwu' (bukan wajib) meskipun belum cukup haulnya.

\section{DAFTAR PUSTAKA}

RI, Kementrian Agama. Al-Qur'an Dan Terjemahnya. Jakarta Timur: Ummul Qura, 2018.

Ad-Dausiri, Muhammad bin Sa’id bin Fahd. "Al-Rātib Al-Taqāudi Dirāsatu Fiqhiyyah," n.d.

al- Utsaimin, Muhammad Shalih. Ensiklopedia Zakat. Pustaka As-Sunnah, n.d.

Al-Bukhārī, Muḥammad ibn Ismā’̄̄l ibn Ibrāhīm. Șah̄̄h Al-Bukhārī. Cet. I. al-Qāhirah: Dār ibn al-Jauzī, 2010.

al-Fauzān, Șālih bin Fauzān bin "Abdullah. "Al-Mulakhkhașal-Fiqhī," Cet. XIV. Kerajaan Saudi Arabia: Dār Ibnu al-Jauz̄̄, 2000.

Al-Ghazali, Muhammad. “Al-Islām Wa Audla’una Al-Iqtishādiyyah,” Cet.I. Mesir: Ḋār

\footnotetext{
${ }^{36}$ Muhammad bin Sa’id bin Fahd Ad-Dausiri, “Al-Rātib Al-Taqāudi Dirāsatu Fiqhiyyah”, h 224.

${ }^{37}$ Abdullah bin Manshur Al-Ghufaili, Nawāzil F̄̄ Zakāt, Cet. I (Dār al-Maymān, 2008), h.278-290.
} 


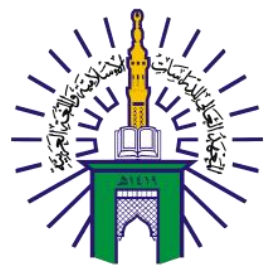

\section{BUSTANUL FUQAHA: \\ JURNAL BIDANG HUKUM ISLAM \\ Vol. 2 No. 3 (2021): Hal. $432-444$ \\ EISSN: 2723-6021 \\ Website: https://journal.stiba.ac.id}

an-Nahdhoti, 2006.

Al-Ghufaili, Abdullah bin Manshur. Nawāzil F̄̄ Zakāt. Cet. I. Dār al-Maymān, 2008.

Al-Qardāwī, Yusuf. "Fikih Al Zakah.” Azar, 2006.

Al-Zuhailī, Wahbāh bin Mustafā. "Al-Fiqhu Al-Islāmī Wa Adillatuhu, Jilid 3 (Damaskus." Damaskus: Dārul fikr, n.d.

Bukit, Elvina Octavia. "Analisis Penerapan Pernyataan Standar Akuntansi Keuangan 18

Mengenai Akuntansi Dana Pensiun Pada Pertamina"." Universitas Hasanuddin, 2012.

Djaelani. Stategi Bazis Dalam Menyiasati Implemantasi UU No. 38 Tahun 1999 Tentang Pengelolaan Zakat. Jakarta: Forum Zakat, 2003.

Ibnu Qudāma, Abdullah bin Aḥmad. "Al-Mugnī.” al-Riyāḍ: Dār 'Ālam al-Kutub, 2015.

Indonesia, President Republik. "Undang-Undang No. 23 Tahun 2011 Tentang Pengelolaan Zakat.” Jakarta, 2011.

Kurnia, Hikmat, and A. Hidayat. Panduan Pintar Zakat. Jakarta: Qultum Media, 2008.

Latumaerissa, Julius R. Bank Dan Lembaga Keuangan Lain. Salemba Empat, 2011.

Mahmuddin, Ronny, Irsyad Rafi, Khaerul Aqbar, and Azwar Iskandar. "Hukummenyegerakan Penyerahan Zakat Harta Dan Zakat Fitrah Di Saat Pandemi Covid-19." BUSTANUL FUQAHA: Jurnal Bidang Hukum Islam 1, no. 2 (2020): 125-36. https://journal.stiba.ac.id/index.php/bustanul/article/view/140.

Mardani. Hukum Islam Dalam Hukum Positif Indonesia. Cet. I. Depok: Rajawali Pers, 2018.

Norman, Efrita, and Enah Pahlawati. "Manajemen Dana Pensiun Syariah." Reslaj : Religion Education Social Laa Roiba Journal 3, no. 2 (2021): 227-35. doi:10.47476/reslaj.v3i2.349.

Qardawi, Yusuf. Fiqhu Zakāh. Cet. II. Bairūt: Muassasat ar- Risālah, 1973.

RI, Kementrian Agama. Al-Qur'an Dan Terjemahnya. Jakarta Timur: Ummul Qura, 2018.

Sālim, Kamāl ibn al-Sayyid. "Ṣaḥīḥ Fiqh Al-Sunnah Wa Adillatuh Wa Tauḍị̄ Mażāhib Al-Aimmah." al-Qāhirah: al-Maktabah al-Tauqīfiyyah, 2003.

Sarwat, Ahmad. Zakat Uang. Cet.I. Jakarta Selatan: Rumah Fikih Publishing, 2019.

Tabrani, Sulaiman bin Ahmad al. "Al Du'aau Li Al Tabrani," Cet I. Baeirūt: dar al kutul al 'alamiyah, 1992.

“Tabungan Hari Tua.” PT.Taspen, 2021. https://taspen.co.id/layanan/detail-tht.

Yassir, Muhammad. "Zakat Tabungan Pensiun," 2020. https://konsultasisyariah.com/17499-zakat-uang-pensiun-dan-klaim-asuransi.html 1.

Yuliani, Marifah. "Manajemen Lembaga Keuangan Non Bank Dana Pensiun Berdasarkan Prinsip Syariah." Journal of Chemical Information and Modeling 17, no. 2 (2019): 221-40.

Yunita, Ani, and Reni Budi Setyaningrum Muhammad Annas. "TANGGUNGJAWAB OTORITAS JASA KEUANGAN SOLO DI LEMBAGA DANA PENSIUN UNIVERSITAS." Masalah-Masalah Hukum 47, no. 4 (2018): 460-78. doi:10.14710/mmh.47.4.2018.460-478.

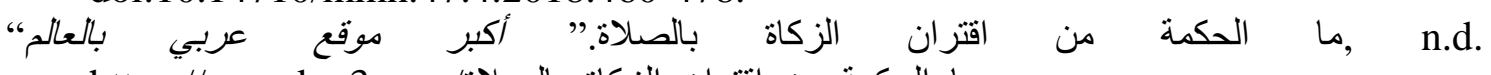

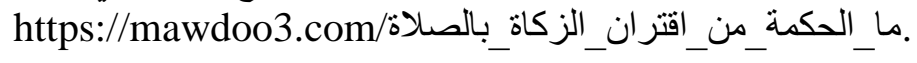

